\title{
Desa wisata sebagai aset soft power Indonesia
}

\section{Tourism village as soft power asset of Indonesia}

\author{
Machya Astuti Dewi \& Sri Issundari \\ Prodi Hubungan Internasional, FISIP, Universitas Pembangunan Nasional (UPN) "Veteran", \\ Jalan Babarsari 2 Yogyakarta, Indonesia \\ E-mail: issundari.ari@gmail.com
}

\begin{abstract}
Tourism village plays significant role for strengthening Indonesia soft power. The experience of Daerah Istimewa Yogyakarta (DIY) province proves that the development of tourism villages contribute in promoting "the power" of Indonesia through art, culture, custom and food to international society. Tourism Villages that located at Sleman, Bantul, Gunungkidul, Kulonprogo and city of Yogyakarta (called as tourism kampong) succeeded in attracting foreigners to stay and live as villagers, enjoy villagers daily live and learn Javanese culture. The study was conducted by observation and interviews. Data were analyzed with descriptive qualitative techniques. Data categorized and given a qualitative analysis of narrative. This research showed that tourism village is a new kind of tourism object that produce a new close relationship between Indonesian people and foreigners, functioned as a tool to make foreigners love Indonesia, prolong their stay in Indonesia, and promote Indonesian culture when they come back to their country. DIY's experience is a best practice for other provinces in Indonesia to develop and promote its own distinctive tradition and culture through tourism villages. Finally, this effort will contribute in supporting Indonesia soft power.
\end{abstract}

Keywords: soft power, people-to-people contact, tourism village, Yogyakarta

\begin{abstract}
Abstrak
Desa wisata memainkan peran penting untuk kekuatan soft power Indonesia. Pengalaman Daerah Istimewa Yogyakarta (DIY) membuktikan bahwa pengembangan desa wisata berkontribusi dalam mempromosikan "kekuatan" dari Indonesia melalui seni, budaya, adat dan makanan untuk masyarakat internasional. Desa wisata yang terletak di Sleman, Bantul, Gunungkidul, Kulonprogo dan Kota Yogyakarta (disebut sebagai kampung pariwisata) berhasil menarik orang asing untuk tinggal dan hidup sebagai warga desa, menikmati desa setiap hari dan belajar budaya Jawa. Penelitian dilakukan dengan melakukan observasi dan wawancara. Data yang terkumpul dianalisis dengan teknik deskriptif-kualitatif. Data dikategorisasikan dan diberikan analisis naratifkualitatif. Hasil penelitian menunjukkan bahwa ini jenis baru objek pariwisata menghasilkan hubungan dekat baru antara orang Indonesia dan orang asing, berfungsi sebagai alat untuk membuat orang asing mencintai Indonesia, memperpanjang mereka tinggal di Indonesia, dan mempromosikan budaya Indonesia ketika mereka kembali ke negara mereka. Pengalaman DIY adalah praktek terbaik untuk provinsi lain di Indonesia untuk mengembangkan dan mempromosikan tradisi tersendiri dan budaya melalui desa wisata. Akhirnya upaya ini akan memberikan kontribusi dalam mendukung soft power Indonesia.
\end{abstract}

Kata kunci: soft power, kontak orang perorang, desa wisata, Yogyakarta

\section{Pendahuluan}

Masyarakat Yogyakarta yang kaya dengan seni budaya dan tradisi kini semakin berpotensi sebagai aktor penting dalam hubungan internasional. Hal ini dibuktikan dengan tumbuh menjamurnya desa wisata di seluruh kabupaten dan kota di Provinsi Daerah Istimewa Yogyakarta (DIY) yang meliputi Kabupaten Sleman, Bantul, Kulonprogo, Gunungkidul dan Kota Yogyakarta. Menurut data statistik kepariwisataan DIY pada tahun 2012 tercatat lebih dari 100 desa wisata tersebar di provinsi ini (Statistik Kepariwisataan DIY 2013). Angka ini memiliki makna bahwa provinsi DIY berpeluang menjadi aset soft power Indonesia, mengingat obyek wisata yang menyajikan keaslian desa, seperti makanan, minuman, arsitektur, kehidupan masyarakat, seni dan budaya masyarakat setempat sangat digemari wisatawan mancanegara. 
Berdasarkan data Statistik Kepariwisataan DIY terdapat kecenderungan peningkatan wisatawan mancanegara (wisman) datang ke Yogyakarta yang berjumlah 139.492 dengan prosentase $8,42 \%$ pada tahun 2009 meningkat menjadi 197.751 tahun 2012 atau menjadi 16,62\%. Adanya peningkatan wisman ini menunjukkan bahwa kota Yogyakarta sebagai bagian dari Indonesia semakin dikenal dan menarik perhatian untuk dikunjungi (lihat tabel 1). Meningkatnya jumlah kunjungan wisman ke Yogyakarta tentunya akan berpengaruh pula pada semakin dikenalnya Indonesia dari sisi sosio kultural dan meningkatkan keinginan untuk datang dan melihat secara langsung. Semakin banyak wisatawan mancanegara tertarik datang ke desa wisata untuk belajar dan merasakan kehidupan sebagai masyarakat desa akan meningkatkan soft power Indonesia di tataran internasional.

Tabel 1.

Jumlah wisatawan mancanegara ke Yogyakarta 2009-2012

\begin{tabular}{ccc}
\hline Tahun & Wisatawan mancanegara & Pertumbuhan $(\%)$ \\
\hline 2009 & 139.492 & 8,42 \\
2010 & 152.843 & 9,57 \\
2011 & 169.565 & 10,94 \\
2012 & 197.751 & 16.62 \\
\hline
\end{tabular}

Sumber: Dinas Kebudayaan \& Pariwisata Provinsi DIY. 2013. Statistik Kepariwisataan DIY tahun 2012. Yogyakarta: Dinas Kebudayaan \& Pariwisata Provinsi DIY.

Wisatawan yang datang ke Yogyakarta didominasi oleh wisatawan dari Eropa, terutama Belanda, disusul Malaysia dan Jepang (lihat tabel 2).

Tabel 2.

Daftar 10 wisatawan asing terbesar ke DIY

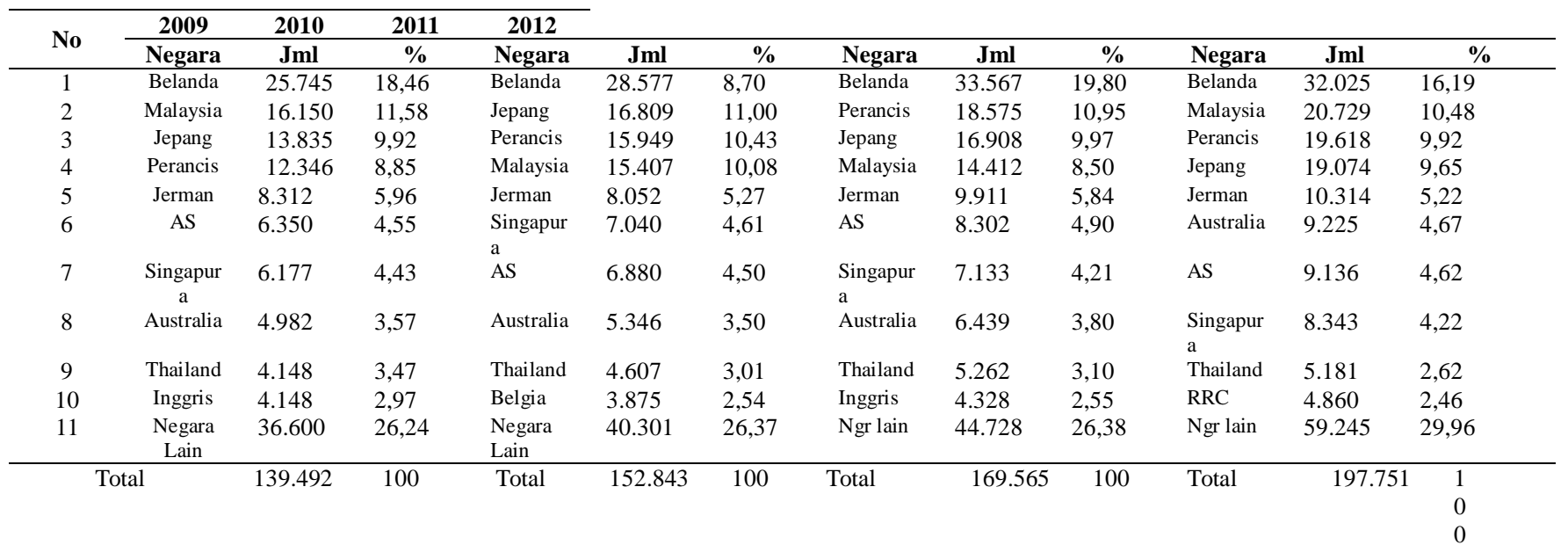

Sumber: Dinas Kebudayaan \& Pariwisata Provinsi DIY. 2013. Statistik Kepariwisataan DIY tahun 2012. Yogyakarta: Dinas Kebudayaan \& Pariwisata Provinsi DIY.

Animo kunjungan wisatawan dari negara-negara tersebut menunjukkan bahwa faktor sejarah dan kedekatan geografis nampak sangat mempengaruhi wisatawan asing yang datang ke DIY. Dilihat dari kedekatan secara historis, Belanda dan Jepang memiliki kaitan historis yang sangat erat dengan Indonesia termasuk dalam hal ini Yogyakarta. Latar belakang sejarah berupa masa penjajahan Belanda dan Jepang sangat mempengaruhi keinginan wisatawan Belanda dan Jepang untuk kembali ke Indonesia terutama mengenang tempat-tempat sejarah yang pernah dialami. Turis Malaysia lebih didasarkan pada kedekatan secara budaya, bahasa dan tradisi sehingga produk-produk budaya Indonesia sudah sangat dekat dengan keseharian masyarakat Malaysia. 
Saat ini banyak desa wisata di Provinsi DIY yang telah sangat dikenal dan mengalami perkembangan pesat. Beberapa di antaranya adalah Brayut, Kembangarum, Kelor, Agrowisata Turi, Kinahrejo, Gamplong dan Pentingsari yang semuanya terletak di kabupaten Sleman. Kemudian di Bantul terdapat Rumah Budaya Tembi, Kebonagung, Giriloyo, Puton dan Kasongan. Di Gunungkidul terdapat desa wisata Bobung, Bleberan dan Nglanggeran. Sementara itu di Kulonprogo ada desa wisata Kalibiru dan Banjaroya. Di kota Yogyakarta terdapat kampung Dipowinatan, Sosromenduran dan Ketandan.

Masing-masing desa wisata memiliki keunikan khas yang berbeda. Sebagai contoh desa wisata Kelor di lereng Gunung Merapi menawarkan wisata makan salak pondoh yang langsung dipetik dari kebun dan wisata sungai Bedhog. Desa wisata Brayut di Sleman menawarkan kerajinan aksesoris. Desa wisata Gamplong dikenal dengan kerajinan tenun. Desa wisata Giriloyo di Bantul menawarkan batik tulis. Desa wisata Kasongan Bantul sudah sangat dikenal sebagai sentra kerajinan gerabah. Sementara itu di desa wisata Kalibiru di Kulonprogo wisatawan bisa menikmati suasana hutan.

Apa yang menarik dari desa wisata adalah potensinya sebagai media untuk mengembangkan soft power Indonesia. Posisi masyarakat lokal sebagai aktor penting yang menciptakan dan mengelola potensi-potensi seni dan budaya untuk "dijual" ke wisatawan domestik dan mancanegara merupakan aset bagi promosi keunikan Indonesia di mata luar negeri. Untuk itulah tulisan ini hendak mendeskripsikan potensi desa wisata di DIY sebagai aset soft power Indonesia.

\section{Metode Penelitian}

Artikel ini merupakan hasil penelitian yang dilakukan di 5 kabupaten dan kota di Provinsi DIY yang mencakup: Kabupaten Sleman, Kabupaten Bantul, Kabupaten Kulonprogo, Gunungkidul dan Kota Yogyakarta.

Penelitian dilakukan dengan melakukan observasi dan wawancara dengan beberapa informan yaitu: pengelola desa wisata, tokoh masyarakat di lokasi desa wisata, masyarakat sekitar, wisatawan asing, serta dinas pariwisata provinsi dan kabupaten. Penggalian informasi dilakukan dengan cara wawancara mendalam untuk mengetahui kondisi desa wisata saat ini baik berupa potensi alam, tradisi, serta seni budaya yang dimiliki; objek dan kegiatan yang ditawarkan; sumber daya manusia yang mengelola desa wisata; animo kunjungan wisatawan mancanegara; serta interaksi mereka dengan wisatawan mancanegara. Untuk lebih memperdalam hasil penelitian juga dilakukan wawancara dengan wisatawan asing di tempat-tempat wisata dengan tujuan untuk mengetahui seberapa besar ketertarikan mereka terhadap desa wisata, interaksi mereka dengan masyarakat setempat dan kesan mereka tentang apa yang mereka lihat atau mereka alami di desa wisata. Data yang terkumpul dianalisis dengan teknik deskriptif-kualitatif. Data dikategorisasikan dan diberikan analisis naratifkualitatif.

\section{Pengertian Soft Power}

Pendekatan soft power kini sedang menjadi tren yang dilakukan oleh banyak negara dalam menghadapi berbagai isu internasional dan regional. Dengan pendekatan ini maka penggunaan kekuatan militer tidak menjadi pilihan dalam politik luar negeri (Detik News 17 Januari 2011). Istilah Soft power mulai diperkenalkan oleh Joseph S. Nye dalam menganalisa perkembangan kebijakan luar negeri AS pasca perang dingin. Soft power dipergunakan setelah sebelumnya Amerika Serikat (AS) lebih banyak menggunaan pendekatan hard power dalam berinteraksi dengan negara lain. Pada saat itu AS lebih banyak menggunakan pendekatan militerisme dan ekonomi dalam menjalankan interaksinya dengan negara lain terutama dalam meningkatkan pengaruh kepada negara lain. Akibat yang muncul ternyata tidak sesuai dengan yang diharapkan AS berupa meningkatnya pengaruh serta aliansi. Apa yang terjadi justru kontraproduktif berupa munculnya sentimen anti-Amerika yang pada intinya menentang kebijakan luar negeri AS. 
Menurut Nye soft power sebenarnya merupakan pelengkap dari hard power. Hard power adalah kemampuan untuk mengontrol pihak lain secara pikiran maupun tindakan dengan menggunakan paksaan daripada kerjasama, biasanya berkaitan dengan penggunaan kekuatan militer, sedangkan soft power lebih cenderung menggunakan power untuk menarik pihak lain dengan nilai atau merupakan kemampuan untuk mempengaruhi agenda pilihan politik yang membuat pihak lain tertarik. Soft power lebih bersifat coopt daripada coersive. Soft power tidak sama dengan pengaruh (influence), lebih dari sekedar bujukan (persuasion) namun soft power adalah kemampuan untuk menarik pihak lain melakukan sesuatu tanpa mereka menyadari bahwa mereka ditarik untuk mengikuti kehendak yang dimaksud. Sumber-sumber soft power adalah sesuatu yang bisa menimbulkan daya tarik (attraction) pihak lain (Nye 2004:7-8). Dengan pendekatan-pendekatan soft power ini maka akan memudahkan negara dalam melaksanakan diplomasinya (Hennida 2010).

Diplomasi publik memiliki kaitan yang erat dengan soft power. Dalam menjalankan kegiatannya, diplomasi publik tidak lagi hanya dilakukan oleh state actors, tapi juga non-state actors. Artinya, pelaku diplomasi bukan lagi hanya diplomat, tetapi juga masyarakat dan media. Ketiga unsur pemerintah, masyarakat, dan media dalam tatanan masyakat demokratis tampil sebagai agen yang memperjuangkan image positif secara simultan melalui praktik dan wacana yang dilakukannya (civic diplomacy). (Cahyaningtyas 2010). Soft diplomacy diartikan sebagai pertukaran gagasan, informasi, seni dan aspek-aspek kebudayaan lain antara negara dan bangsa, dengan harapan bisa menciptakan pengertian bersama. Keberhasilan soft diplomacy ini sangat tergantung pada reputasi pelaku dalam komunitas internasional serta pertukaran informasi di antara para pelaku. Soft diplomacy bersumber dari soft power yang melatarbelakangi poin dari topik yang dibicarakan. Berbeda dengan hard power yang berwujud seperti military power atau economic power, soft power lebih atraktif untuk dijalankan karena dilatarbelakangi oleh sesuatu yang khas yang dimiliki oleh sebuah negara atau bangsa. Soft power ini akan lebih mudah diterima oleh negara-negara lain karena dapat menjadi ajang untuk berteman antar diplomat yang menjadi aktor utama dalam berdiplomasi. Berikut di bawah ini akan digambarkan spektrum hard power dan soft power.

Tabel 3.

Hard power dan soft power

\begin{tabular}{|c|c|c|c|c|}
\hline & \multicolumn{3}{|c|}{ HardPower } & Soft power \\
\hline & Coercion & inducement & $\begin{array}{l}\text { Agenda } \\
\text { setting }\end{array}$ & attraction \\
\hline Spectrum of & & & & co-op \\
\hline
\end{tabular}

$\begin{array}{llcl}\begin{array}{l}\text { Most likely } \\ \text { resources }\end{array} & \begin{array}{l}\text { Force } \\ \text { Sanction }\end{array} & \begin{array}{c}\text { payment } \\ \text { bribes }\end{array} & \begin{array}{l}\text { Institution values Culture } \\ \text { Policies }\end{array}\end{array}$

Sumber : Nye, Joseph S. 2004. Soft Power The Means to Success in World Politics. USA: Public Affairs. Hal. 8.

Berdasarkan gambar tersebut dapat dilihat bahwa soft power memiliki beberapa sarana untuk mempengaruhi agenda setting negara asing serta menarik menarik perhatian (attrack) publik asing yaitu melalui: nilai-nilai politik, budaya dan kebijakan luar negeri (Nye 2004). Untuk mendukung soft power, sarana yang bisa dimanfaatkan saat ini tidak hanya melibatkan pemerintah, namun sudah meluas melalui hubungan antar parlemen dan masyarakat. Duta Besar bukan hanya mewakili pemerintah tetapi juga negara baik parlemen, pemerintah maupun people-to-people. Kondisi dunia saat ini mendorong munculnya gaya diplomasi baru yang mengutamakan pembentukan jaringan informal selain jalur formal melalui perwakilan. Tren diplomasi saat ini lebih banyak mengedepankan second track diplomacy. Diplomasi ini didefinisikan sebagai upaya mencapai 
kepentingan nasional suatu negara melalui understanding, informing and influencing foreign audiences. Jika proses diplomasi tradisional dikembangkan melalui mekanisme government to government relations, maka model diplomasi ini lebih ditekankan pada government to people atau bahkan people-to-people contact. Secara singkat people-to-people contact lebih menekankan arti pentingnya suatu hubungan "interpersonal" di antara warga/masyarakat/bangsa. Idealnya, people-topeople contact adalah bersifat positif, nyaris tanpa jarak dan substansinya, juga senantiasa bermuatan persahabatan/perdamaian.

Sumber soft power berupa budaya merupakan salah satu sumber potensial yang bisa dimanfaatkan. Sumber budaya ini merupakan serangkaian nilai dan aktifitas yang menciptakan makna bagi masyarakat. Bentuknya bisa beragam seperti sastra, seni dan pendidikan yang muncul di dalam masyarakat dengan berfokus pada mass entertainment. Melalui cara-cara yang komunikatif, perwujudannya akan berupa dialog, diplomasi, kerjasama, atau kerja bersama. Dengan pendekatan ini Indonesia dapat diangkat di mata dunia internasional lewat makanan/kuliner (nasi goreng, kopi luwak), pariwisata (Bali dan pulau-pulau lain), kerajinan tradisional (batik, handycraft dan lain-lain), kesenian (angklung) dan olahraga (bulutangkis dan pencaksilat).

\section{Desa wisata di Yogyakarta}

Pengembangan desa wisata merupakan salah satu kebijakan yang dikerjakan secara serius oleh pemerintah provinsi DIY. Setidaknya keseriusan ini dibuktikan dengan lahirnya berbagai kebijakan untuk mendorong pengembangan desa wisata. Dinas Kebudayaan dan Dinas Pariwisata provinsi DIY secara kontinyu melakukan berbagai kajian dan upaya untuk mempromosikan dan mendorong potensi desa wisata. Bahkan sejak tahun 1995 Gubernur DIY telah mengeluarkan surat keputusan (SK) Gubernur Nomor 325.KPTS/1995 tertanggal 24 November 1995 yang menegaskan tentang pembentukan Desa Bina Budaya sebanyak 32 desa (Dinas Kebudayaan Provinsi DIY 2005:I-1).

Sejalan dengan kebijakan pemerintah mengenai pengembangan desa wisata ini kemudian mulai diikuti upaya masing-masing desa wisata untuk menarik perhatian wisatawan asing ke desa wisata yang ada di DIY. Hasilnya telah terlihat bahwa setiap tahun sejak 2008-2012 terjadi terdapat peningkatan jumlah kunjungan wisatawan mancanegara maupun domestik (lihat tabel 4).

Tabel 4.

Jumlah kunjungan wisatawan asing ke desa wisata di DIY 2008-2012

\begin{tabular}{ccccccc}
\hline TAHUN & Wisman & $\begin{array}{c}\text { Tumbuh } \\
(\mathbf{\%})\end{array}$ & Wisnus & $\begin{array}{c}\text { Tumbuh } \\
(\boldsymbol{\%})\end{array}$ & $\begin{array}{c}\text { Wisman \& } \\
\text { Wisnus }\end{array}$ & $\begin{array}{c}\text { Tumbuh } \\
(\mathbf{\%})\end{array}$ \\
\hline 2008 & 128.660 & 24,64 & 1.156 .097 & 0,86 & 1.284 .757 & 2,83 \\
2009 & 139.492 & 8,42 & 1.286 .565 & 11,29 & 1.426 .057 & 11,00 \\
2010 & 152.843 & 9,57 & 1.304 .137 & 1,37 & 1.456 .980 & 2,17 \\
2011 & 169.565 & 10,94 & 1.438 .129 & 10,27 & 1.607 .694 & 10,34 \\
2012 & 197.751 & 16,62 & 2.162 .422 & 50,36 & 2.360 .173 & 46,80
\end{tabular}

Sumber: Dinas Kebudayaan \& Pariwisata Provinsi DIY. 2013. Statistik Kepariwisataan DIY tahun 2012. Yogyakarta: Dinas Kebudayaan \& Pariwisata Provinsi

Data tersebut menunjukkan bahwa tingkat pertumbuhan kunjungan wisatawan mancanegara ke desa wisata cenderung meningkat yaitu 8,42\% di tahun 2009 meningkat menjadi 10,94\% ditahun 2011 dan mencapai $16,62 \%$ di tahun 2012. Meskipun demikian pertumbuhan wisatawan asing ke desa wisata tidak sebanding dengan peningkatan kunjungan wisatawan lokal ke desa wisata yaitu $11,29 \%$ pada tahun 2009 dan mencapai 50,36\% di tahun 2012. Terlepas dari tren kunjungan wisatawan mancanegara yang tidak sebesar wisatawan lokal, data tersebut mengisyaratkan bahwa desa wisata 
merupakan aset yang sangat potensial untuk dikenal di mata masyarakat internasional mengingat tawaran kehidupan khas masyarakat lokal dapat dirasakan secara langsung bagi wisatawan asing.

Sejalan dengan peningkatan kunjungan turis mancanegara, perkembangan desa wisata pun mengalami pertumbuhan yang pesat. Pertumbuhan desa wisata tidak hanya terjadi di Indonesia, trend popularitas desa wisatapun diseluruh dunia juga meningkat. Menurut laporan dari OECD, negara bagian AS Wyoming (dengan populasi 512.000) memperkirakan bahwa pariwisata berasal dari desa wisata di daerah-daerah perbatasan bernilai lebih dari \$ 1 miliar per tahun. Sementara itu, Britain's Countryside Commission memperkirakan bahwa pengunjung ke desa wisata di Inggris menghabiskan £ 3 000.000.000 pada tahun 1986: Dari angka ini $£ 1100$ juta berasal dari orang-orang menghabiskan setidaknya satu malam di pedesaan, dan sisanya berasal turis yang sedang dalam perjalanan (OECD 1994:23). Pertumbuhan desa wisata ini tidak terlepas dari beberapa kondisi yaitu meningkatnya stress masyarakat kota dengan segala kompleksitas di daerah perkotaan sehingga menimbulkan keinginan untuk mencari suasana yang berbeda, meningkatnya kesadaran akan arti penting lingkungan melalui kunjungan kedaerah pedesaan yang relatif terjaga kelestarian lingkungan, peningkatan pendidikan masyarakat serta dukungan teknologi berupa komunikasi serta transportasi (Rural Tourism 2010). Berangkat dari kecenderungan tersebut maka tidaklah mengherankan apabila pemerintah daerah bersama-sama dengan masyarakat berupaya untuk menciptakan desa wisata sebagai tempat tujuan wisata yang unik, yang berbeda dengan objek wisata pada umumnya, terutama tempat wisata yang berbasis kreativitas dan partisipasi masyarakat. Keinginan ini bertujuan untuk menarik perhatian wisatawan agar betah dan mau kembali datang berkunjung. Bapak Sinang Sukanta yang pernah menjabat sebagai kepala bidang destinasi wisata di Dinas Pariwisata DIY menjelaskan:

“... selama ini kan kalau informasi yang selalu disampaikan adalah Borobudur, Prambanan, Kraton, dan Malioboro. Setelah datang dan lihat sekali dua kali, kalau anak muda pasti mikir what's next akhirnya kami mencoba mencari dan menciptakan destinasi-destinasi baru. Nah destinasi baru ini kan didasarkan UU Pariwisata no 10 tahun 2009 yang menyatakan bahwa sudah selayaknya masyarakat menjadi pelaku bukan hanya penonton, nah... kami mencoba menumbuhkan desa wisata. Desa wisata itu bukan bentukan pemerintah namun inisiatif masyarakat. Kalau yang bentukan pemerintah saya yakin tidak akan jalan karena pelaku sebenarnya adalah masyarakat (Wawancara dengan bapak Sinang Sukanta tanggal 8 Juli 2014).

Saat ini di seluruh provinsi DIY tercatat lebih dari seratus desa wisata, namun tidak semuanya berkembang dengan baik. Beberapa desa wisata yang populer dan sudah berkembang antara lain sebagai berikut:

\section{Desa Wisata Sambi}

Desa Wisata Sambi terletak di Jalan Kaliurang Km.19,2. Padukuhan Sambi Desa Pakembinangun Kecamatan Pakem Kabupaten Sleman DIY. Desa ini memiliki beragam potensi wisata yang menarik untuk dikunjungi oleh wisatawan. Panorama desa yang sejuk karena berada di lereng Merapi, asri dan nyaman menjadi daya tarik tersendiri bagi wisatawan untuk melakukan kegiatan menyusuri desa (tracking). Kegiatan lain yang bisa dilakukan wisatawan adalah belajar menanam padi dan memelihara ikan, memerah sapi, melakukan outbound, mengikuti kegiatan kenduri, sadranan, ruwahan, serta belajar kesenian tradisional. Jika ingin berinteraksi dan merasakan kehidupan masyarakat desa, wisatawan dapat menginap di homestay rumah-rumah penduduk sekitar (desawisatasleman. wordpress.com).

\section{Desa Wisata Kembangarum}

Desa wisata Kembangarum terletak di Kabupaten Sleman. Desa wisata ini menekankan edukasi dan alam sebagai sajian bagi pengunjung, terutama anak-anak. Di lokasi ini terdapat sanggar lukis dan perpustakaan yang dibangun untuk anak-anak. Selain pendidikan, desa wisata Kembangarum juga menawarkan sarana permainan tradisional di halaman pendopo yang dijadikan sanggar lukis. Berbagai permainan tradisional seperti enggrang, engklek, dakon, gobak sodor, dan lainnya dapat 
dimainkan di lokasi tersebut. Kolam pemancingan ikan dan kolam renang alami merupakan arena bermain yang tidak kalah menarik (Desa Wisata Kembangarum).

\section{Desa Wisata Pentingsari}

Dusun Pentingsari juga terdapat di Sleman. Daerah ini berbentuk seperti semenanjung yang di sisi sebelah barat terdapat lembah yang sangat curam yaitu kali Kuning dan sebelah selatan terdapat lembah yang berupak Goa Ledok/Ponteng dan Gondoran sebelah timur terdapat lembah yang curam yaitu Kali Pawon dan sebelah utara merupakan dataran yang dapat berhubungan langsung dengan tanah di sekeliling kelurahan Umbulharjo sampai ke pelataran gunung Merapi. Dusun Pentingsari terdiri dari dua dusun yaitu Bonorejo dan Pentingsari. Desa ini ditetapkan sebagai desa wisata pada tanggal 15 Mei 2008. Berbagai objek wisata ditawarkan di desa ini, antara lain: pancuran suci Sendangsari, luweng, rumah joglo, wisata alam, batu dakon, batu persembahan, ponteng (pertemuan dua sungai), dan tracking (Desa Wisata Sleman 2014).

\section{Desa Wisata Krebet}

Desa wisata Krebet terletak di Dusun Krebet, Desa Sendangsari, Kecamatan Pajangan, Bantul, Yogyakarta, kurang lebih $12 \mathrm{~km}$ barat daya Kota Yogyakarta. Berbagai produk kerajinan yang dihasilkan oleh warga Krebet adalah seperti topeng, wayang, almari, asesoris rumah tangga, patung kayu, kotak perhiasan, dan hiasan batik kayu lainnya. Desa wisata Krebet juga menawarkan fasilitas menginap bagi wisatawan yang ingin mengenal lebih jauh tentang proses pembuatan kerajinan batik kayu atau sekedar ingin menikmati suasana alam pedesaan Krebet yang masih asri atau untuk belajar bertani kepada warga setempat. Warga Krebet juga rutin menyelenggarakan sebuah upacara Merti Dusun Krebet. Upacara ini adalah sebuah bentuk ungkapan rasa syukur warga Krebet kepada Tuhan Yang Maha Esa atas hasil bumi yang melimpah.

\section{Desa Wisata Puton}

Desa wisata Puton terletak di Puton, Jetis, Bantul Yogyakarta. Desa ini memiliki beragam potensi wisata, di antaranya Watu Ngelak (batu besar di pinggir sungai Opak, tempat dahulu Sultan Agung berhenti beristirahat dalam perjalanan untuk bertemu Nyai Roro Kidul di pantai Selatan). Potensi lain adalah peternakan dan perikanan, potensi budaya dan kesenian tradisional, pondok makan dan pemancingan, Arung Sungai Opak serta area perkemahan. Kerajinan yang dimiliki oleh Dusun puton adalah pahat batu, kerajinan kayu, seni lukis, batik, kerajinan gedebog pisang, dan sudi takir. Di samping kerajinan potensi seni budaya yang dimiliki oleh Desa Puton di antaranya adalah karawitan, pedalangan/wayang kulit, kethoprak remaja, tari tradisional, Gejog Lesung, Sholawatan, Pertunjukan Band pemuda dan Hadroh. Kuliner yang khas dari Desa Puton ini adalah industri peyek, kripik, kacang sangan, serta sego wiwit, masakan ikan segar, masakan tradisional di pondok wisatanya (Wawancara dengan bapak Kohar 22 Mei 2014).

\section{Desa Wisata Bleberan}

Desa Bleberan adalah desa yang berada di sisi sebelah barat wilayah kabupaten Gunungkidul. Desa wisata Bleberan memiliki beberapa potensi wisata yang layak untuk dikembangkan, antara lain wisata alam air terjun Sri Gethuk dengan tebing yang indah, situs purbakala (menhir) dan Rafting di sungai Oyo. Sedangkan untuk wisata budaya desa ini masih memegang teguh adat kebiasaan masyarakat Jawa yang bisa disaksikan dalam berbagai upacara adat, misalnya kenduri Rasulan, kenduri Nyadranan, kenduri Robyongan, kesenian Reog, Jathilan, Doger, Slawatan, hadroh dan kesenian wayang kulit. 


\section{Desa Wisata Nglanggeran}

Desa Wisata ini terletak di desa Nglanggeran, Patuk, Gunungkidul. Wisata yang ditawarkan adalah gunung api purba dan embung (telaga) besar. Di Nglanggeran wisatawan dapat bermalam di rumahrumah penduduk, berinteraksi dengan penduduk sambil mempelajari seni budaya Jawa, seperti membatik topeng, membuat kerajinan dari janur, belajar tari tradisional jathilan dan reog, ikut kenduri, menangkap dan melepas ikan di sungai, menanam padi, serta belajar memasak kuliner Jawa khas desa Nglanggeran. Wisatawan juga dapat menikmati berbagai kegiatan rekreatif, seperti rock climbing dengan 28 jalur dan tracking.

\section{Aset untuk Soft Power}

Keberadaan desa wisata yang menawarkan program live in akan meningkatkan interaksi saling pemahaman antara masyarakat Indonesia dengan masyarakat internasional. Wisatawan asing dapat melihat, terlibat dan merasakan secara langsung kehidupan sehari-hari masyarakat Indonesia. Pengalaman ini akan meningkatkan pemahaman mereka mengenai Indonesia. Sementara itu, masyarakat Indonesia juga dapat belajar mengenai budaya para peserta tersebut sehingga tercipta pemahaman yang lebih baik. Kondisi ini akan mendorong people-to-people contact yang lebih nyata. Kegiatan ini juga merupakan salah satu upaya untuk memaksimalkan salah satu aset power yang dimiliki Indonesia dalam kerangka soft power diplomacy yaitu seni dan budaya. Aset ini merupakan aset paling potensial yang dimiliki Indonesia dalam rangka membina hubungan baik dengan berbagai negara serta mempromosikan Indonesia dalam dunia hubungan internasional (Kompas 15 Desember 2010).

Di desa wisata para wisatawan asing tinggal bersama warga desa untuk mengenal dan mempelajari aspek kehidupan masyarakat desa. Mereka bersosialisasi membaur dengan warga desa melakukan aktivitas sehari-hari mulai dari bercocok tanam menanam padi di sawah, membuat batu bata, menggiring bebek, menangkap ikan di sungai, membuat ketupat dari janur, membuat sudi dan takir untuk kenduren, memasak bersama dengan ibu-ibu warga desa untuk menyiapkan kenduren, mengikuti upacara kenduren, belajar membuat batik dan gerabah dari tanah liat, belajar menari dan menabuh gamelan.

Mayoritas wisatawan asing yang mengunjungi desa wisata mengungkapkan ketertarikan mereka pada aktivitas dan pengalaman yang mereka lalui selama tinggal di desa wisata. Salah satu wisatawan yang mengatakan pernah mengunjungi desa wisata adalah Fransisca, warga negara Amerika yang sudah empat kali datang ke Yogyakarta. Fransisca menceritakan bahwa ia sangat senang berada di desa wisata, terutama karena ia bisa belajar membatik:

I like Jogja. Because the culture, the food is good and so many tourist places... I know about tourism village. I know from my friend who lived in Indonesia. I did (lived in tourism village) but I don't remember name of the place. It was in 2013 but I don't remember wher it is. My friend told me about that place, so we visiting that place together. I love how to make batik... although just one day in tourism village I feel happy (Wawancara dengan Fransisca 26 Juni 2014).

Brett Calis, pemuda dari Australia yang pernah tinggal di Yogyakarta untuk mengikuti program internasional dari universitasnya Flinders University mengaku bahwa ia sangat tertarik dengan desa wisata. Menurut Brett tinggal di desa wisata yang berbasis budaya, misalnya tinggal bersama penduduk, belajar memainkan gamelan, menanam padi, lebih menarik dibandingkan wisata petualangan semacam gua Pindul. Selama berada di desa wisata Brett sangat antusias memainkan gamelan Jawa (Calis 2014).

Bagi wisatawan asing desa wisata menawarkan pengalaman hidup yang menarik dibandingkan sekedar mengunjungi objek wisata. Menariknya adalah karena mereka bisa merasakan sendiri kehidupan masyarakat Jawa (Yogyakarta) karena tinggal, berinteraksi langsung dan terlibat dalam kegiatan masyarakat desa. Daniel Krauss, seorang pemuda dari Jerman mengaku sangat menikmati 
interaksi dan kegiatan bersama masyarakat desa. Selama tinggal di Yogyakarta Daniel bahkan belajar bahasa Jawa dengan sangat antusias (Krauss 2014).

Beberapa Desa Wisata memang telah memiliki pelanggan tetap dari negara tertentu yang setiap tahun datang ke lokasi. Salah satunya adalah Desa Wisata Puton Watungelak di Bantul yang setiap tahun kedatangan tamu mahasiswa asing dari Korea Selatan dan mahasiswa asing yang mengikuti program internasional di beberapa PTN dan PTS di Yogyakarta. Ibu Soraya Isfandari yang mengelola desa wisata Puton Watungelak di Bantul menceritakan:

Setahun sekali rombongan dari universitas Hanseo Korea berkunjung secara rutin di desa ini. Mereka melakukan kegiatan sosial semacam KKN: mengajar Bahasa Korea, memberikan bibit durian dan jeruk nipis dan sapi. Ada rumah Korea... Dana dari pemerintah Korea untuk pembangunan desa ini. .. Rombongan yang rutin datang adalah mahasiswa internasional dari UGM dan Sanata Dharma.... Setiap bulan selalu ada rombongan mahasiswa asing yang datang (Soraya 2014).

Hal serupa juga dialami oleh desa wisata Kalakijo Kabupaten Bantul yang saat ini masih dalam taraf pembangunan infrastruktur. Setiap tahun tamu dari Jepang selalu datang dan menikmati wisata alam, wisata budaya dan dan wisata kuliner di lokasi ini. Kepala Dusun Kalakijo yang sekaligus menjadi pengelola desa wisata Kalakijo: bapak Sareh Sapardi mengemukakan:

Secara umum orang Jepang biasa ke sini. Tetapi di luar Jepang ada Perancis, Inggris, Jerman itu ada. Mereka studi banding disini menginap selama 3 bulan, 1 minggu, 2 hari. Mereka studi banding pendidikan. Kunjungannya tidak setiap bulan, tetapi kalau setiap tahun pasti ada. Orangnya ganti-ganti. Biasanya bulan September... Ya seperti KKN. Kita kemarin membicarakan masalah penanggulangan bencana. Yang ke sini mahasiswa ada, dosen juga ada. Tapi selalu kalangan pelajar (Sapardi 2014).

Beberapa desa wisata yang telah maju bahkan sering menggelar event internasional, misalnya desa wisata Pentingsari di Sleman. Ibu Kuskasriyati Kepala Bidang Penguatan Kapasitas Dinas Pariwisata DIY menjelaskan bahwa desa wisata Pentingsari telah sering menggelar event internasional. Bahkan pada bulan September tahun 2014 digelar Forum Muslimah Sedunia (World Muslimah Forum) di Yogyakarta yang salah satu acaranya dilangsungkan di desa wisata Pentingsari (Kuskasriyati 2014).

Namun demikian menurut Sinang Sukanta, tidak semua wisatawan asing familiar atau mengenal desa wisata. Menurut pengamatannya wisatawan asing yang paling banyak berkunjung ke desa wisata adalah dari Belanda. Sinang mengemukakan alasannya:

Belanda termasuk yang repeater. Dari 10 terbesar wisatawan DIY itu memang Belanda masih peringkat teratas... Itu kan kaitannya dengan mereka pernah menjajah di sini. Kemudian mereka cerita pada anak cucunya bahwa mereka pernah tinggal disini di Indonesia, Jawa, Yogya. Jadi pernah saya bertemu dengan wisatawan yang hanya ingin mengunjungi Kotabaru dan Kotagede, kalau di Jakarta ada kota tua. Jadi mereka mungkin punya pengalaman masa lalu. Ini yang erat kaitannya (Sukanta 2014).

Apa yang membanggakan provinsi DIY adalah bahwa jumlah kunjungan wisatawan asing terus meningkat setiap tahun, termasuk animo untuk mengunjungi desa wisata dan belajar tentang seni dan budaya masyarakat Jawa. Hal ini berdampak positif untuk semakin memperkenalkan Indonesia di forum internasional.

Upaya mendorong potensi desa wisata sebagai aset soft power Indonesia juga sejalan dengan langkah provinsi DIY untuk menjadi creative city. Saat ini banyak negara berupaya mendorong pengembangan industri kreatif sebagai media pencitraan dan promosi dari kekayaan budaya suatu negara. Indonesia memiliki industri kreatif yang sangat kaya ragam, mulai dari kuliner, kesenian hingga konten digital. Industri kreatif ini menjadi salah satu kekuatan Indonesia untuk bisa bersaing di pentas global. 
Industri ini bisa menjadi soft power dalam mengangkat Indonesia di mata dunia. Salah satu yang menjadi kekuatan dari muatan industri kreatif adalah filosofi yang ada di belakangnya.

Dalam mendorong agar industri kreatif di Indonesia mendapatkan pengakuan internasional, maka Kementerian Pariwisata dan Ekonomi Kreatif mengusulkan beberapa kota di Indonesia agar bisa memperoleh label The Creative City Network (Kota Kreatif) oleh UNESCO, salah satunya adalah Yogyakarta. Banyak sekali manfaat yang bisa didapatkan Yogyakarta apabila memperoleh label tersebut.

Namun langkah yang telah ditempuh Kementerian Pariwisata dan Ekonomi Kreatif perlu didukung dengan upaya serius dari pemerintah daerah. Brand Yogyakarta sebagai The Creative City Network (di mana kunjungan wisatawan asing ke desa wisata bisa menjadi salah satu tolok ukurnya) masih perlu ditingkatkan. Terlebih lagi belum semua wisatawan asing mengenal keberadaan desa wisata. Dari hasil wawancara dengan wisatawan asing yang ditemui di beberapa sentra tempat wisata DIY (Prambanan, kraton, Malioboro dan Prawirotawan), sebagian besar wisatawan asing mengatakan belum mengenal tempat-tempat yang dikemas sebagai desa wisata. Sebagian kecil di antaranya mengetahui beberapa desa wisata di DIY, tetapi belum pernah singgah, dan sebagian kecil lainnya mengetahui dan pernah bermalam di desa wisata. Mereka ini adalah pelajar atau mahasiswa yang mengikuti program internasional di beberapa Perguruan Tinggi Negeri dan Swasta di DIY. Oleh karenanya promosi desa wisata perlu terus ditingkatkan agar lebih popular di kalangan wisatawan asing, mengingat arti penting keberadaan desa wisata yang memiliki potensi untuk mendorong soft power Indonesia.

\section{Simpulan}

Pengembangan desa wisata memiliki potensi besar dalam memperkuat soft power Indonesia. Setidaknya pengalaman provinsi DIY telah menunjukkan kecenderungan positif bahwa pertumbuhan desa wisata memberikan kontribusi dalam memperkenalkan "kekuatan" Indonesia melalui adat, seni, budaya dan kuliner kepada masyarakat internasional. Potensi ini bisa menjadi contoh bagi provinsiprovinsi lain di Indonesia untuk mengembangkan desa wisata dengan keunikan tradisi dan budaya masing-masing, sehingga akan semakin menyokong soft power Indonesia di forum internasional.

Salah satu kekuatan desa wisata di Yogyakarta adalah bahwa desa wisata tumbuh dari inisiatif masyarakat, bukan dorongan atau paksaan dari pemerintah. Potensi ini juga berkorelasi positif dengan peluang untuk semakin mengembangkan people-to-people contact yang akan memberikan kontribusi penting dalam memperkuat diplomasi Indonesia. Oleh karenanya dukungan pemerintah untuk mengembangkan potensi desa wisata perlu terus ditingkatkan, terutama bagi desa wisata yang masih berada pada tahap perintisan.

\section{Daftar Pustaka}

Cahyaningtyas J (2011) Peran civic diplomacy dalam mendukung investasi kapital dan strategi simbolik Indonesia. Masyarakat Kebudayaan dan Politik 22(1): 8-16.

Calis B (2014) [Personal Communication] 13 Juni.

Desa wisata kembangarum [Diakses 4 Mei 2014] http:// desawisatasleman. wordpress.com/desawisata-kembangarum/]

Desa wisata pentingsari [Diakses 4 Mei 2014] http://desawisatasleman.wordpress.com/desa-wisatapentingsari/Yogyakarta.

Desa wisata sambi [Diakses 4 Mei 2014] http://desawisatasleman.wordpress.com/desa-wisata-sambi/.

Dewangga TA (2012) “Diplomasi melalui Soft Power", diakses dari www.setkab.go.id/artikel6305-diplomasi-mell-soft-power. [diakses 4 Mei 2014].

Dinas Kebudayaan \& Pariwisata Provinsi DIY (2005) Laporan Dinas Kebudayaan Provinsi Yogyajarta: Dinas Kebudayaan \& Pariwisata Provinsi DIY. 
Dinas Kebudayaan \& Pariwisata Provinsi DIY (2013) Statistik Kepariwisataan DIY 2012. Yogyakarta: Dinas Kebudayaan \& Pariwisata Provinsi DIY.

Diplomasi Publik Indonesia-Seni dan Budaya dalam Kompas. 15 Desember 2010

Fransisca (2014) [Personal Communication] 26 Juni.

Government of Alberta (2010) Rural Tourism-An Overview, Canada: Agriculture \& Rural Development.

Hennida C (2010) Diplomasi publik dalam politik luar negeri. Masyarakat, Kebudayaan dan Politik 22(1): 17-23.

Krauss D (2014) [Personal Communication] 13 Juni.

Kuskasriyati (2014) [Personal Communication] 18 Juli.

Nye JS (2004) Soft power the means to success in world politics. USA: Public Affairs.

Organization for Economic Co-operation and Development (1994) Tourism strategies and rural develoment, Paris: Organization for Economic Co-operation and Development.

Sapardi S (2014) [Personal Communication] 10 Juli.

Soft Power Indonesia dalam Pembangunan Asia dalam. Detiknews. 17 Januari 2011.

Soraya (2014) [Personal Communication] 22 Mei.

Sukanta S (2014) [Personal Communication] 8 Juli. 